\title{
Photoacclimation of four marine phytoplankton species to irradiance and nutrient availability
}

\author{
P. A. Staehr*, P. Henriksen, S. Markager \\ Department of Marine Ecology, National Environmental Research Institute, Frederiksborgvej 399, PO Box 358, \\ 4000 Roskilde, Denmark
}

\begin{abstract}
Photoacclimation to different light and nutrient regimes was studied in 4 common marine phytoplankton species from northern European coastal waters. Significant changes were observed for all species in their cellular nutrient content, pigment packaging and composition, and chl a-specific in vivo light absorption $\left(a^{*}{ }_{\text {chla }}(\lambda)\right)$. From exponential to stationary growth, the $C: N$ and carotenoid:chl a ratios increased, while the cellular chl a content decreased. All phytoplankton species acclimated to increasing irradiance by reducing their cellular chl a content and increasing the carotenoid:chl a ratio, resulting in higher chl a-specific absorption coefficients $\left(a^{*}{ }_{\text {chla }}\right)$. Similar results were observed for $\mathrm{N}$-depleted cultures. Although acclimation to different irradiance and nutrient conditions introduced a substantial variability in pigment composition and intracellular pigment con-

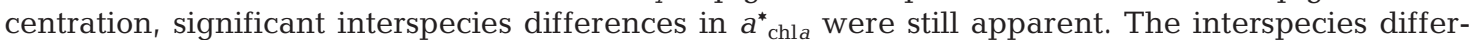
ences were primarily due to differences in cell size, which covaried with pigment packaging and composition. On this basis, we suggest that optical acclimation (i.e. changes in pigment composition and packaging) to the prevailing growth conditions (light, temperature and nutrient availability) is less important than differences in phytoplankton composition (dominant cell size and pigment composition) for the variation in $a^{*}{ }_{\text {chla }}(\lambda)$ of natural phytoplankton communities.
\end{abstract}

KEY WORDS: Phytoplankton - Chl a-specific in vivo light absorption · Photoacclimation . Pigmentation Resale or republication not permitted without written consent of the publisher -

\section{INTRODUCTION}

Light absorption by photosynthetic pigments of phytoplankton cells can have a profound effect on the optical characteristics of a water column and may contribute significantly to the attenuation of light with depth. Light absorption by natural phytoplankton populations also constitutes an important component in models estimating algal biomass from remote sensing (Gordon \& Morel 1983) and in models of primary production in the ocean (Platt \& Sathyendranath 1988, Morel \& André 1991, Platt et al. 1995, Sathyendranath et al. 1995). The significant spatial and temporal variability commonly found in light absorption by phytoplankton must be understood if these models are to be

*E-mail: pst@dmu.dk optimized for a particular region or season (Stuart et al. 1998).

The spectral chl a-specific in vivo light absorption $\left(a^{*}{ }_{\text {chla }}(\lambda)\right)$ provides an estimate of the amount of light absorbed by intact phytoplankton cells from knowledge of ambient irradiance and chl a concentration. Significant variability in $a^{*}{ }_{\text {chla }}(\lambda)$ has been found over regional scales (Hoepffner \& Sathyendranath 1992, Lutz et al. 1996, Staehr et al. unpubl.). This variability has been explained by changes in the abundance of accessory pigments relative to chl a (Bricaud et al. 1983, Sathyendranath et al. 1987, Berner et al. 1989, Sosik \& Mitchell 1991) as well as changes in cell size and pigment concentration, also known as the package effect (Morel \& Bricaud 1981, Sathyendranath et al. 1987, Mitchell \& Kiefer 1988, Sosik \& Mitchell 1991, Kirk 1994). The chl a-specific absorption coefficient $\left(a^{*}{ }_{\text {chla }}\right)$ has been found to decrease from oligotrophic,

(C) Inter-Research $2002 \cdot$ www.int-res.com 
over mesotrophic to eutrophic waters (e.g. Yentsch \& Phinney 1989, Bricaud et al. 1995, Cleveland 1995, Staehr et al. unpubl.). Yentsch \& Phinney (1989) suggested that this pattern results from the presence of small cells with high $a^{*}{ }_{\text {chla }}$ in oligotrophic waters shifting to larger cells with lower $a^{*}{ }_{\text {chla }}$ in more nutrient-rich environments. This pattern, formulated as the 'trophic regime' hypothesis, was supported by Cleveland (1995) and Staehr et al. (unpubl.).

However, there could be other potential sources of variation in the $a^{*}$ chla. Several studies with phytoplankton monocultures have shown that composition and intracellular concentration of pigments, along with the $a^{*}{ }_{\text {chlar }}$ respond relatively quickly to changes in growth irradiance (e.g. Sathyendranath et al. 1987, Falkowski \& LaRoche 1991) and availability of inorganic N (e.g. Berner et al. 1989, Herzig \& Falkowski 1989, Chalup \& Laws 1990, Sosik \& Mitchell 1991). It is also known that the $a^{*}{ }_{\text {chla }}$ can vary significantly between different phytoplanton species (e.g. Bricaud et al. 1983, Falkowski et al. 1985, Geider et al. 1986, Bricaud et al. 1988). The $a^{*}{ }_{\text {chla }}$ is, thus, basically dependent on cellular pigmentation and cell size/morphology. These characteristics exhibit interspecies differences as well as intraspecies differences resulting from physiological acclimation to varying growth conditions (light, temperature and nutrient availability). An essential question is, therefore, what is the relative influence of short-term acclimation versus long-term adaption of the phytoplankton community structure for the naturally observed variability in the $a^{*}{ }_{\text {chla }}(\lambda)$ ?

In the present study, we investigated the optical acclimation of different phytoplankton monocultures to a realistic range of growth conditions. The experiments were performed with batch cultures of 4 species of marine phytoplankton belonging to classes differing in cell size and pigmentation.

\section{MATERIALS AND METHODS}

Algal cultures and culture conditions. Phytoplankton cultures, isolated from northern European waters, were obtained from the Scandinavian Culture Centre for Algae \& Protozoa, University of Copenhagen, and from the Marine Biological Laboratory, University of Copenhagen. Four species, Ditylum brightwellii (Bacillariophyceae), Brachiomonas sp. (Chlorophyceae), Pyramimonas disomata (Prasinophyceae) and Pseudoscourfieldia marina (Prasinophyceae), differing with respect to pigmentation and size, were used in the study. The algae were grown as batch cultures in 21 flasks with magnetic stirring and gentle aeration at $15^{\circ} \mathrm{C}$. For each species, duplicate cultures were grown
Table 1. Vitamin and trace element solutions for culture medium

\begin{tabular}{|lrlr|}
\hline \multicolumn{2}{|l}{ Vitamin solution } & \multicolumn{2}{c|}{ Trace element solution } \\
\hline In 1 l demineralized $\mathrm{H}_{2} \mathrm{O}:$ & \multicolumn{2}{c}{ In $500 \mathrm{ml}$ demineralized $\mathrm{H}_{2} \mathrm{O}:$} \\
Thiamine HCL & $200 \mathrm{mg}$ & $\mathrm{MnCl}_{2}$ & $178 \mathrm{mg}$ \\
Biotin & $1 \mathrm{mg}$ & $\mathrm{ZnCl}_{2}$ & $23 \mathrm{mg}$ \\
$\mathrm{B}_{12}$ & $1 \mathrm{mg}$ & $\mathrm{CoCl}_{2} \cdot 6 \mathrm{H}_{2} \mathrm{O}$ & $119 \mathrm{mg}$ \\
& & $\mathrm{CuSO}_{4} \cdot 5 \mathrm{H}_{2} \mathrm{O}$ & $5 \mathrm{ml} 0.025 \% \mathrm{w} / \mathrm{v}$ \\
& & $\mathrm{Na}_{2} \mathrm{MoO}_{3} \cdot 2 \mathrm{H}_{2} \mathrm{O}$ & $5 \mathrm{ml} 0.146 \% \mathrm{w} / \mathrm{v}$ \\
\hline
\end{tabular}

at 3 levels of irradiance ranging from 40 to $300 \mu \mathrm{mol}$ photons $\mathrm{m}^{-2} \mathrm{~s}^{-1}$ in a 16:8 h light:dark cycle. Irradiance was measured using a $4 \pi$ sensor from Biospherical placed inside a culture flask without water. Cultures were grown in an artificial medium based on Sea Salt (Sigma, product no. S 9883) at salinities of 20 to 30 ppt. Sea Salt was dissolved in demineralized water, sterilized at $90^{\circ} \mathrm{C}$ for $2 \mathrm{~h}$ and cooled prior to aseptical addition of $0.5 \mathrm{ml} \mathrm{l}^{-1} \mathrm{NaFeEDTA}$ solution $(0.3 \% \mathrm{w} / \mathrm{v}), 25 \mu \mathrm{l}$ Se solution $\left(\mathrm{SeO}_{2}, 11.1 \% \mathrm{w} / \mathrm{v}\right), 1 \mathrm{ml}$ vitamin solution (Table 1) and $1 \mathrm{ml}$ trace element solution (Table 1). Nitrogen $\left(\mathrm{NaNO}_{3}\right.$ solution, $\left.7.5 \% \mathrm{w} / \mathrm{v}\right)$ and phosphorus $\left(\mathrm{NaH}_{2} \mathrm{PO}_{4} \cdot \mathrm{H}_{2} \mathrm{O}\right.$ solution, $0.5 \%$ w/v) were supplied aseptically to give the following final N:P concentrations ( $\mu \mathrm{M})$ : 25:5 (N-depleted), 85:5 (Redfield ratio) and 85:1 (N-repleted). This experimental design allowed us to examine the combined effect of nutrient availability along with the effect of different irradiance levels on changes in different optical properties of the selected phytoplankton species.

Sampling. Samples for pigment analysis, phytoplankton in vivo light absorption, cell size, and particulate $\mathrm{C}$ and $\mathrm{N}$ were collected for duplicate cultures once during exponential and once during stationary growth phase. The growth was determined from cell counts by microscopic enumeration of cells in $1 \mathrm{ml}$ Sedgwick-Rafter chambers Ditylum brightwellii and a hemocytometer for Pseudoscourfieldia marina. The growth of Brachiomonas sp. and Pyramimonas disomata was determined from cell counts using a particle counter (El-zone 180XY, Micromeritcs). Growth rate $(\mu)$ during exponential growth was calculated according to Eq. (1):

$$
\mu=\left(\ln B_{2}-\ln B_{0}\right) / 2
$$

where $B_{2}$ represents the cell concentration (counts $\mathrm{ml}^{-1}$ ) $1 \mathrm{~d}$ after sampling and $B_{0}$ the cell concentration $1 \mathrm{~d}$ before sampling.

Pigment analysis. For pigment analysis, 25 to $150 \mathrm{ml}$ of culture were filtered onto $25 \mathrm{~mm}$ Advantec GF 75 glass fiber filters and immediately stored in liquid $\mathrm{N}$. Filters were, subsequently, transferred to $3 \mathrm{ml} \mathrm{99.8 \%}$ acetone, sonicated on ice for $15 \mathrm{~min}$ and left to extract for $24 \mathrm{~h}$ at $4{ }^{\circ} \mathrm{C}$ prior to filtering $(0.2 \mu \mathrm{m})$ into HPLC vials 
containing $1 \mathrm{ml}$ water. HPLC analyses were performed on a Shimadzu LC 10A system with a Supercosil C18 column $(250 \times 4.6 \mathrm{~mm}, 5 \mu \mathrm{m})$ using a slight modification of the Wright et al. (1991) method as described in Schlüter \& Havskum (1997). This method does not provide full baseline-separation of lutein and zeaxanthin, so these pigments were manually separated based on their absorption spectra recorded by photodiode array detection. In Pseudoscourfeldia marina, Mg-2,4divinyl pheoporphyrin $a_{5}$ monomethyl ester (Mg DVP) was tentatively quantified using the HPLC response factor for chl $C_{1+2}$. All other pigments were identified by retention times and absorption spectra identical to those of authentic standards, and quantified against standards purchased from the International Agency for ${ }^{14} \mathrm{C}$ Determination, Hørsholm, Denmark.

Phytoplankton absorption. Spectral absorption (300 to $800 \mathrm{~nm}$ by $0.5 \mathrm{~nm}$ ) of particulate material was determined by using the quantitative filtering technique described by Kishino et al. (1985) using a Shimadzu UV-2401PC UV-Vis recording spectrophotometer equipped with an integrating sphere. Samples were either measured immediately or preserved in liquid nitrogen until analysis within 2 mo. No significant effect of this storage was observed on the absorption measurements. Optical density spectra were smoothed using a $10 \mathrm{~nm}$ running average and corrected for background absorption by subtracting the average optical density measured between 750 and $800 \mathrm{~nm}$. The corrected optical densities were converted into particulate absorption coefficients $\left(a_{\text {par }}\right)$ using the $\beta$-correction factor given by Bricaud \& Stramski (1990):

$$
a_{\mathrm{par}}(\lambda)=2.3 \times \mathrm{OD}(\lambda) \times \frac{A F}{V} \times\left(1.63 \times \mathrm{OD}(\lambda)^{-0.22}\right)
$$

where $V$ is filter volume, $A F$ is effective filter area, OD is optical density of the particulate material and $\lambda$ is the measured wavelength. Samples were measured before and after methanol extraction in order to correct for absorption by detritus $\left(a_{\text {det }}\right)$. Samples of Brachiomonas sp. and Pyramimonas disomata were, however, corrected for detritus absorption by use of the numerical method developed by Bricaud \& Stramski (1990). Absorption spectra were studied per unit concentration of chl a (chl $a+$ pheopigments) and per unit concentration of total pigment content (sum of all HPLC measured pigments). $a^{*}{ }_{\text {chla }}(\lambda)$ was calculated according to:

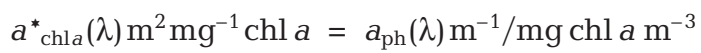

where the absorption by phytoplankton pigments $\left(a_{\mathrm{ph}}\right)$ was determined as:

$$
a_{\mathrm{ph}}(\lambda)=a_{\mathrm{par}}(\lambda)-a_{\mathrm{det}}(\lambda)
$$

Spectrally averaged chl a specific absorption coefficient $\left(\hat{a}^{*}{ }_{\text {chl }}\right)$ was calculated by summing $a^{*}{ }_{\text {chla }}$ over all measured wavelengths (400 to $700 \mathrm{~nm} \times 0.5 \mathrm{~nm}$ ) and dividing by the number of wavelengths measured ( $\mathrm{n}=601$; Markager \& Vincent 2001).

$$
\hat{a}^{*}{ }_{\mathrm{chl} a}=\frac{\sum_{400}^{700} a^{*}{ }_{\mathrm{chl} a}(\lambda)}{n}
$$

By replacing chl a with the sum of all pigments (mg Tpig $\mathrm{m}^{-3}$ ) in Eq. (3), $a^{*}$ Tpig $(\lambda)$ was calculated.

Cell size. Measurements of phytoplankton cell dimensions were used to determine phytoplankton biovolume and cell size of each treatment. For Ditulum brightwellii, cell dimensions were calculated into biovolume (BV) assuming cells to be shaped as a cylinder with a spherical cross-section, while the shape of a sphere was applied for all other species to calculate the BV. Finally, assuming cells to be spherical, the average equivalent spherical diameter (ESD) of each water sample was calculated:

$$
\mathrm{ESD}=2 \times\left(\frac{3 \times \mathrm{BV}}{4 \pi}\right)^{\frac{1}{3}}
$$

Parameterization of the specific absorption coefficient. The specific absorption coefficient for spherical particles $a^{*}$ can be described as:

$$
a^{*}=(3 / 2) \frac{Q_{\mathrm{a}}}{C_{\mathrm{i}} \times d}
$$

where $Q_{\mathrm{a}}$ represents the dimensionless absorption efficiency and can be defined as the fraction of the photons incident on the geometric cross-section of the cell that is absorbed by the cell, $c_{\mathrm{i}}$ represents the intracellular chl a concentration ( $\mathrm{mg} \mathrm{chl} \mathrm{a} \mathrm{m}^{-3}$ cell) and $d$ is the cell diameter $(\mathrm{m})$ (Morel \& Bricaud 1981). The absorption efficiency, $Q_{\mathrm{a}}$, can be calculated from the absorption coefficient for phytoplankton $a_{\mathrm{ph}}(\lambda)$ :

$$
Q_{a}(\lambda)=\frac{a_{\mathrm{ph}}(\lambda) \times V}{\left(\pi d^{2} / 4\right) \times N}
$$

Here, $N$ is the number of cells in a volume $(V)$ of the suspension and cells are assumed to be spherical and homogeneous (Morel \& Bricaud 1981) allowing the use of ESD as a measure of cell size $(d)$. Substituting $a_{\mathrm{ph}}(\lambda)$ with the spectrally averaged phytoplankton absorption $\left(\hat{a}_{\mathrm{ph}}\right)$ in Eq. (7) provides a measure of the spectrally averaged absorption efficiency, which can be used to evaluate the variation in $\hat{a}^{*}{ }_{\text {chl }}$. According to Morel \& Bricaud (1981), the variation of $a^{*}$ at a given wavelength results mainly from the combined variations of $c_{\mathrm{i}}$ and $d$, and less from variations in $Q_{\mathrm{a}}$. Therefore, to further evaluate the variation in $\hat{a}^{*}{ }_{\text {chla }}$, we calculated the 'relative optical length' of the phytoplankton community, defined as the product of $C_{\mathrm{i}}$ and $d$ having the units $\mathrm{mg} \mathrm{chl} \mathrm{a} \mathrm{m}^{-2}$ cell. In our calculations, the calculated ESD was used for estimating $d$ and $C_{\mathrm{i}}$. 


\section{RESULTS}

\section{Cellular acclimation to different growth conditions}

Four phytoplankton monocultures were sampled during exponential and stationary growth (Fig. 1). During exponential growth, cellular $\mathrm{C}: \mathrm{N}$ ratios were rather similar both within and between the different phytoplankton species, except for Brachiomonas sp. which had a significantly higher $\mathrm{C}: \mathrm{N}$ ratio in $\mathrm{N}$-depleted cultures (Fig. 2). This result suggests that these cultures were already in the transition to the stationary growth phase at the time of sampling. A significant increase in the overall $\mathrm{C}: \mathrm{N}$ ratio, as well as an increase in the variation of the $\mathrm{C}: \mathrm{N}$ ratios, was observed when cultures reached the stationary growth phase. Thus, the average $\mathrm{C}: \mathrm{N}$ ratio for all species increased from $12.3 \pm 0.8$ to $22.4 \pm 1.6$ (mean $\pm \mathrm{SE}$ ). This was mainly due to a decrease in cellular $\mathrm{N}$ content (Table 2), which on average for all 4 phytoplankton species decreased 3-fold ( $89 \pm 19$ to $27 \pm 6 \mathrm{pg} \mathrm{N}$ cell ${ }^{-1}$ ) whereas cellular carbon content increased by $17 \%$ (592 \pm 246 to $692 \pm$ $311 \mathrm{pgC} \mathrm{cell}{ }^{-1}$ ). The decrease in cellular $\mathrm{N}$ content from exponential to stationary growth phase of Redfield and N-repleted cultures indicates that the applied $\mathrm{N}$ concentration of the Redfield and N-repleted cultures (85 $\mu \mathrm{M}$ nitrate) was not sufficient to prevent $\mathrm{N}$ starvation of these cultures, which therefore may actu- ally not have grown under Redfield or N-replete conditions at the time of sampling. Another possibility for the increased C:N ratio under Redfield and N-replete conditions is that $\mathrm{C}$ accumulated in the cells because $\mathrm{C}$ fixation exceeded the growth rate, possibly restricted by low phosphorus availability.

Two-way ANOVA evaluating the effect of species and dissolved inorganic nitrogen (DIN) availability confirmed that increasing DIN availability reduced the $C: N$ ratio in both the exponential $(p=0.009)$ and stationary growth phases $(p<0.0001)$. A similar test of the effect of species and irradiance level gave no significant effect of irradiance ( $p>0.05)$, irrespective of growth phase. Therefore, nutrient availability significantly affected the $\mathrm{C}: \mathrm{N}$ ratios, while growth irradiance had no significant impact (Fig. 2) on the ratio.

The relative optical length of the phytoplankton cultures was significantly (2-way ANOVA, p < 0.0001) dependent on the particular phytoplankton species, the growth phase and the growth conditions, especially irradiance (Fig. 3) of the phytoplankton. The relative optical length of the phytoplankton increased with increasing phytoplankton cell size in both growth phases. The relative optical length significantly decreased (Student-Newman-Keuls pairwise comparison, $\mathrm{p}<0.05)$ from the exponential $(75.7 \pm 7.3 \mathrm{mg} \mathrm{chl} \mathrm{a}$ $\left.\mathrm{m}^{-2}\right)$ to the stationary growth phase $(32.8 \pm 4.5$; Fig. 3$)$. The observed decrease was caused by a 2 -fold de-

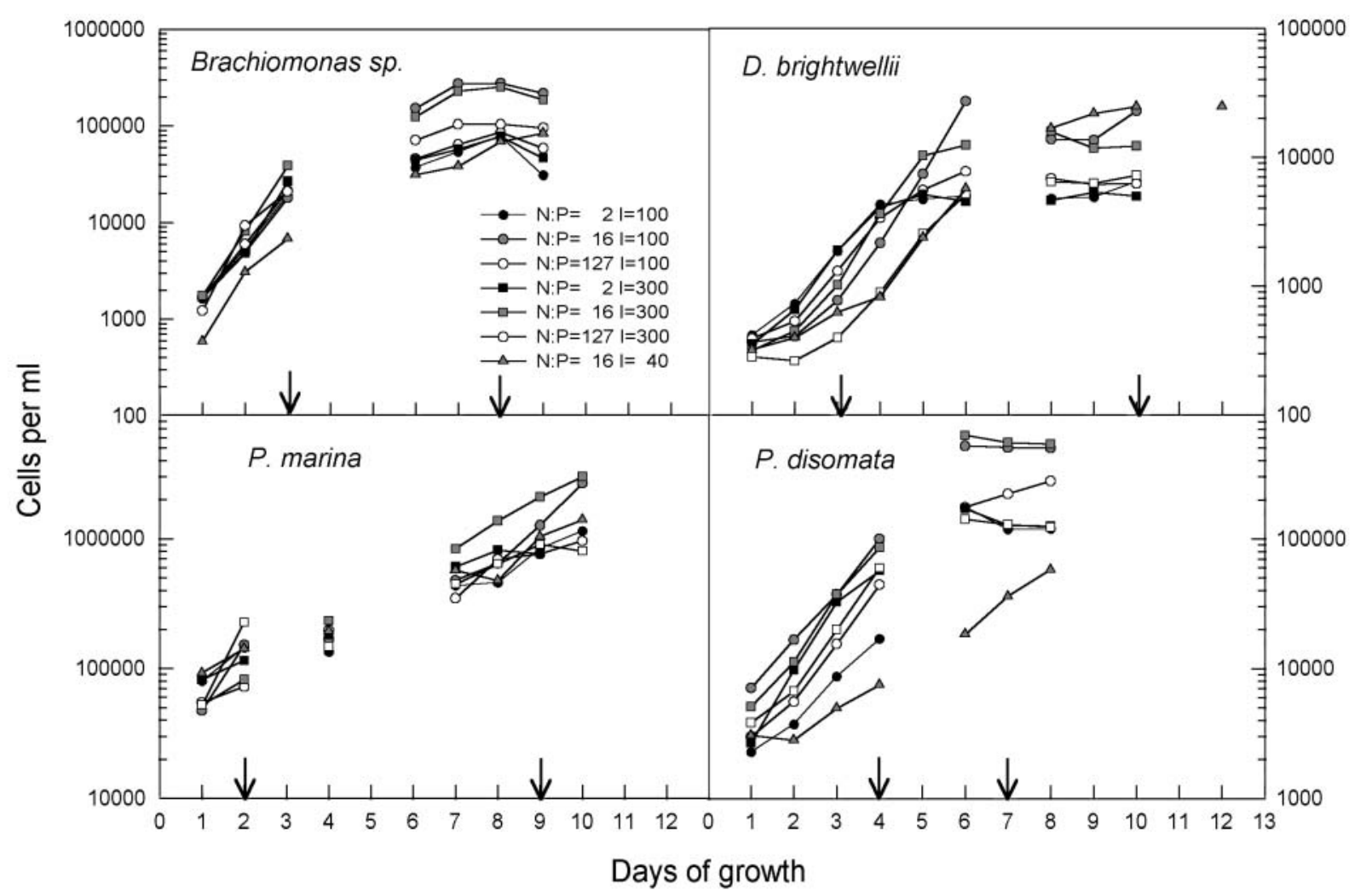

Fig. 1. Phytoplankton growth in media with molar N:P ratios of 5 (depleted DIN), 16 (Redfield-ratio) and 85 (repleted DIN) under different irradiances $\left(40,100\right.$ and $300 \mu \mathrm{mol}$ photons $\left.\mathrm{m}^{-2} \mathrm{~s}^{-1}\right)$. Arrows indicate days of sampling. All data are the average of 2 replicates. See Table 2 for full species names 


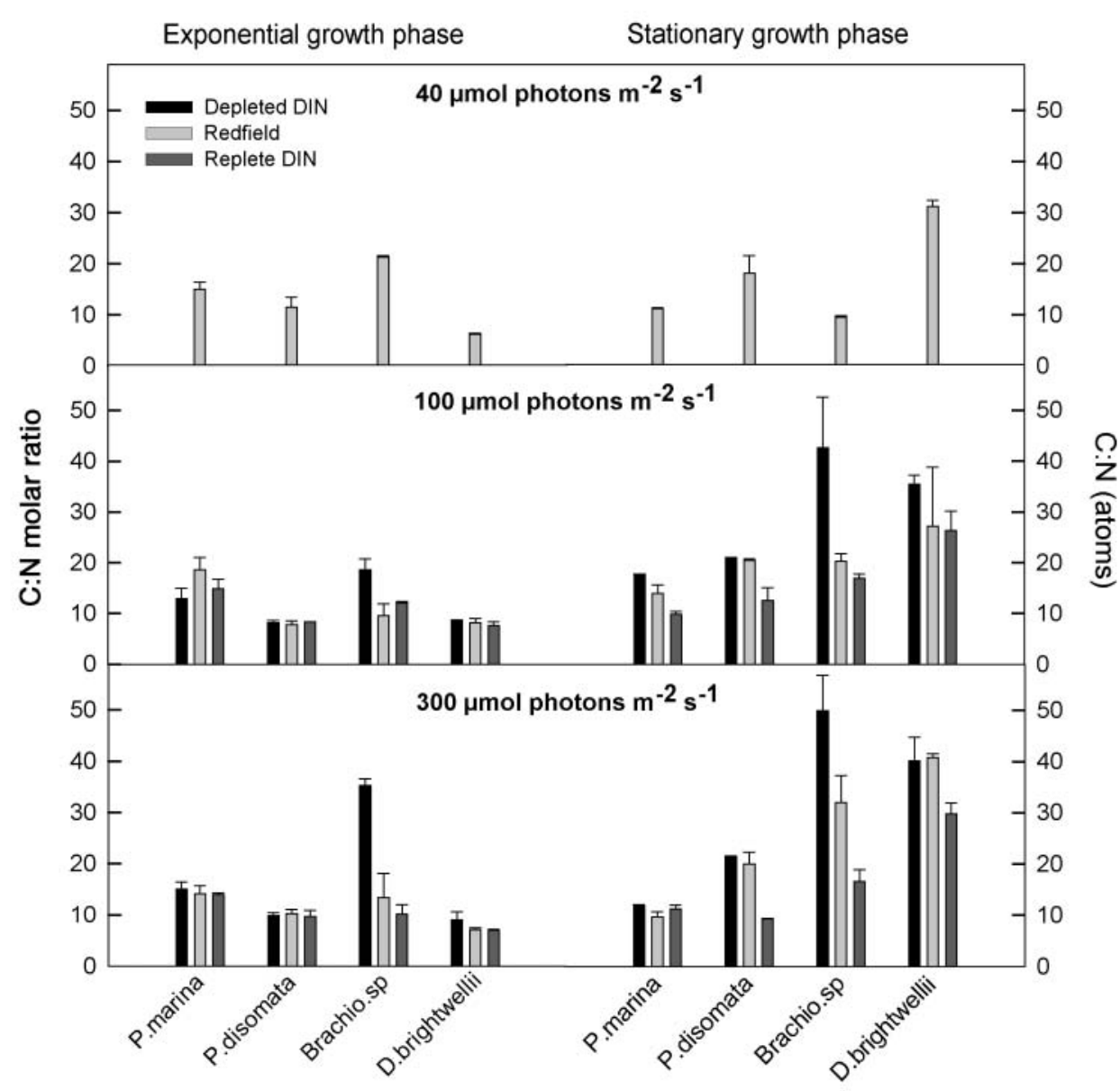

Fig. 2. Particulate C:N molar ratio of phytoplankton species sampled in exponential and stationary growth. Phytoplankton species are presented in order of increasing cell size. All data are average \pm 1 SE $(n=2)$. See Table 2 for full species names

crease in the intracellular $\mathrm{chl}$ a concentration, from 8.9 \pm 1.0 to $4.3 \pm 0.7 \mathrm{mg} \mathrm{chl} \mathrm{a} \mathrm{m}{ }^{-3}$ cell, while the overall phytoplankton cell size showed a small, but significant increase from $11.6 \pm 1.6$ to $13.4 \pm 1.8 \mu \mathrm{m}$ equivalent to $16 \%$ (2-way ANOVA, $\mathrm{p}<0.0001)$ corresponding to the increase in cellular $\mathrm{C}$ content. Cultures grown at high irradiance generally had a lower relative optical length irrespective of growth phase (Fig. 3). Two-way ANOVA confirmed the negative effect of irradiance on the relative optical length in both the exponential and stationary growth phases $(p=0.0004$ and $p<0.0001$, respectively), while increasing $\mathrm{N}$ availability had a significant positive effect on the relative optical length during stationary growth $(p=0.008)$, but no significant effect during exponential growth $(\mathrm{p}=0.91)$.

Pigment composition differed significantly (2-way ANOVA, $\mathrm{p}<0.0001$ ) between phytoplankton species and growth phases (Fig. 4). A significant increase (2-way ANOVA, p < 0.0001) in the carotenoid:chl $a$ ratio was observed going from exponential to stationary growth for all species. At $300 \mu \mathrm{mol}$ photons $\mathrm{m}^{-2}$ $\mathrm{s}^{-1}$, the mean carotenoid:chl a ratio for all species increased from $0.50 \pm 0.02$ to $0.69 \pm 0.03$. Both nutrient availability and irradiance significantly affected the carotenoid:chl $a$ ratio. These observations were supported by a 2-way ANOVA confirming the positive effect of irradiance on the ratio during both exponential $(\mathrm{p}=0.0004)$ and stationary growth $(\mathrm{p}<$ 0.0001). Irrespective of growth phase, increasing irradiance reduced both the cellular chl $a$ and carotenoid content of the species (Table 2). However, since the cellular chl a content decreased more than the cellular carotenoid content, the carotenoid:chl a ratio increased. A 2-way ANOVA test confirmed that the carotenoid to $\mathrm{chl} a$ ratio of the algae significantly decreased with increasing availability of DIN during stationary growth $(p<0.0001)$. This was, however, not found during exponential growth $(\mathrm{p}=0.16)$. Overall, the carotenoid:chl a ratio increased with increasing irradiance and N-starvation (2-way ANOVA, p < 0.0001). Changes in the carotenoid:chl a ratios were primarily caused by changes in the cellular chl a content, while the cellular carotenoid content varied less (Table 2). 


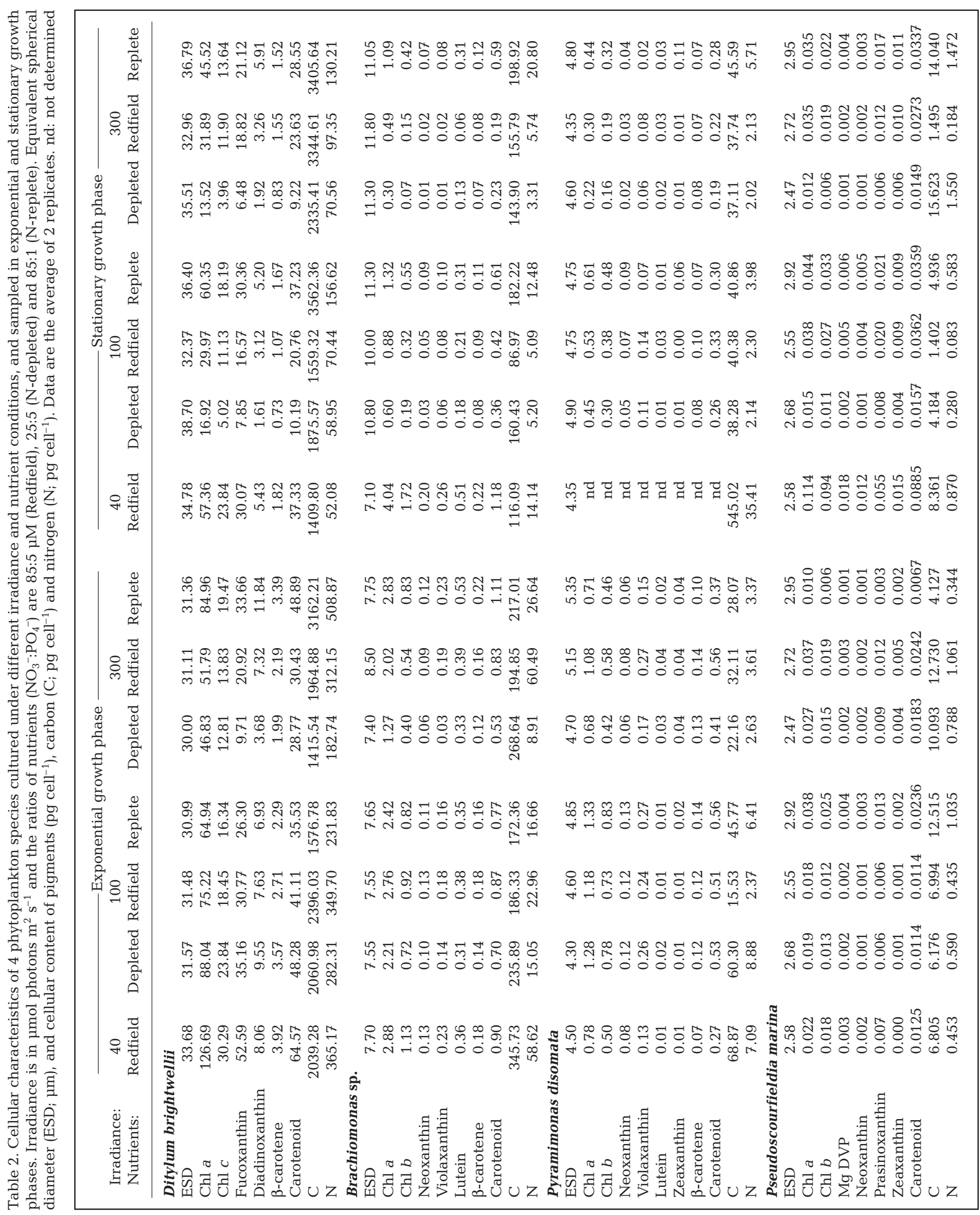




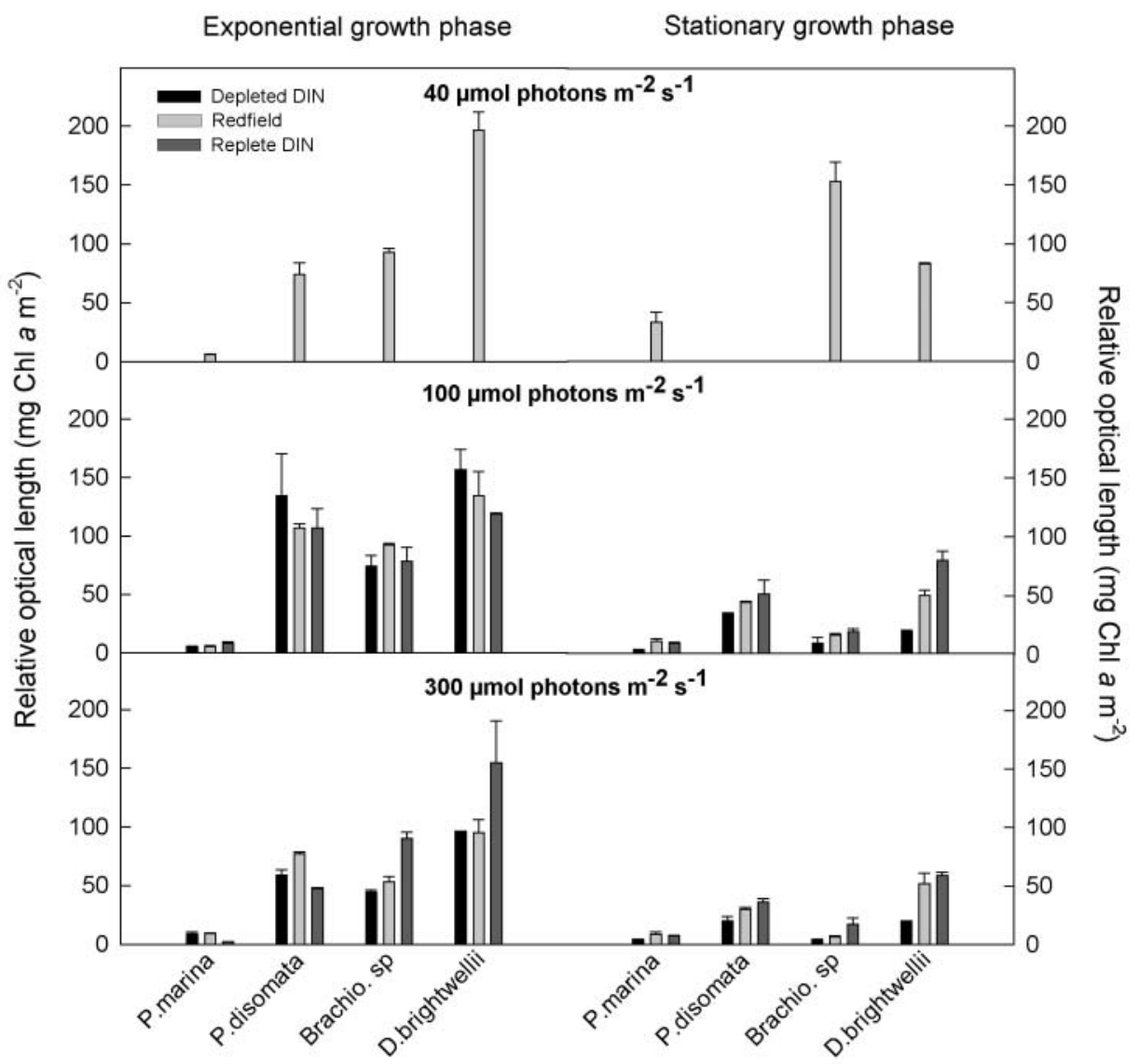

Fig. 3. Optical thickness (mg chl a m${ }^{-2}$ cell) of phytoplankton species sampled in exponential and stationary growth. Phytoplankton species are presented in order of increasing cell size. All data are average \pm 1 SE $(n=2)$. See Table 2 for full species names

\section{Effects on chl a-specific in vivo absorption}

Differences were found in the in vivo spectral light absorption of the 4 phytoplankton species when normalized to both chl $a$ and total pigment concentration (Fig. 5). The differences were most apparent when the specific absorption coefficient was calculated on the basis of chl a. Overall, Pseudoscourfieldia marina had the highest values, followed by Pyramimonas disomata, Brachiomonas sp. and Ditylum brightwellii. This rank pattern suggests that the $a^{*}$ chla decreased with increasing phytoplankton cell size. Further, the overall level of the chl $a$-specific absorption spectra increased slightly from exponential to stationary growth $(12.4 \pm$ 1.3 to $15.4 \pm 1.2 \mathrm{~m}^{2} \mathrm{~g}^{-1} \mathrm{chl}$ a), while the total pigmentspecific absorption spectra did not change notably $\left(5.7 \pm 0.4\right.$ to $6.8 \pm 0.5 \mathrm{~m}^{2} \mathrm{~g}^{-1} \mathrm{chl}$ a). Comparing spectra at selected wavebands using a 2-way ANOVA, furthermore, documented significant differences in $a^{*}{ }_{\text {chla }}(\lambda)$ spectra between species and growth phase $(\mathrm{p}<0.05)$ while $a^{*}$ Tpig $(\lambda)$ spectra were only significantly different between species $(p<0.05)$. For this purpose, we chose the wavebands applied by the SeaWiFS satellite in the
400 to $700 \mathrm{~nm}$ region $(412,443,490,555$ and $670 \mathrm{~nm})$ as these wavebands are particularly important for remote sensing applications.

An analysis of the changes in spectral shape of the chl $a$-specific absorption spectra showed that the coefficient of variation (CV) of the entire spectra decreased from $79 \pm 2$ in Pseudoscourfieldia marina to $77 \pm 3$ in Pyramimonas disomata to $69 \pm 4$ in Brachiomonas sp. to $67 \pm 4$ (mean CV $\pm 95 \% \mathrm{CL}$ ) in Ditylum brightwelli. The inverse relationship between the spectral CV and cell size (ESD) of the algae was further confirmed by Spearman rank correlation analysis $\left(\mathrm{r}_{\mathrm{s}}=-0.48, \mathrm{p}<\right.$ $0.0001)$, thereby confirming that the chl $a$-specific absorption spectra became significantly flatter with increasing cell size of the phytoplankton.

The spectrally averaged $\hat{a}^{*}$ chla was coefficient significantly (2-way ANOVA, $\mathrm{p}<0.001$ ) different depending on the phytoplankton species, growth phase, $\mathrm{N}$ availability and irradiance level (Fig. 6). In addition to the above-mentioned increase in $\hat{a}^{*}$ chla from exponential to stationary growth, irradiance had a positive effect on the overall level of $\hat{a}^{*}{ }_{\text {chla }}$. Thus, overall $\hat{a}^{*}{ }_{\text {chla }}$ for all species increased from $9.4 \pm 2.2$ over $13.1 \pm 1.4$ to $16.0 \pm$ 


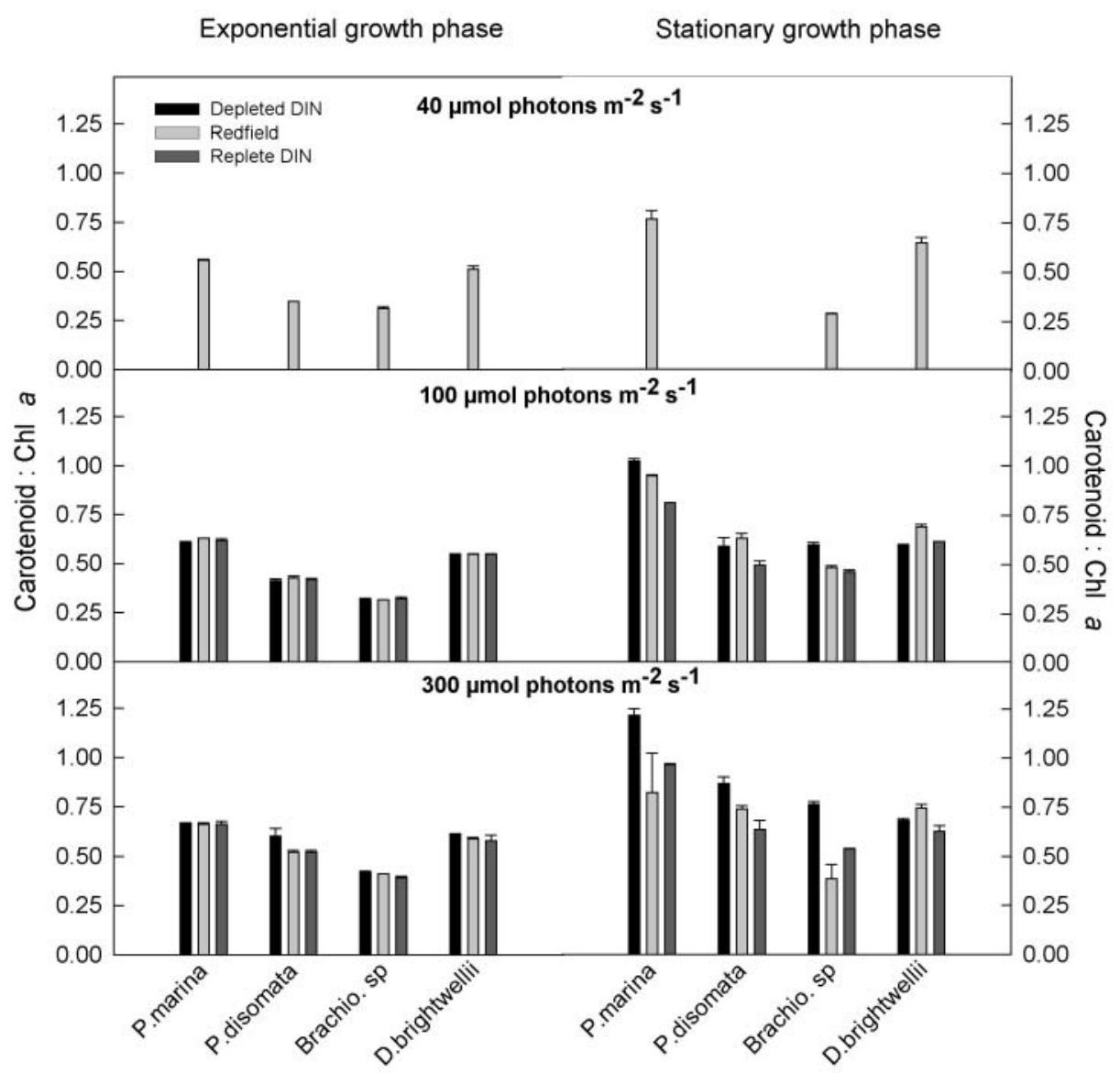

Fig. 4. Carotenoid:chl a weight ratio of phytoplankton species sampled in exponential and stationary growth. Phytoplankton species are presented in order of increasing cell size. All data are average \pm 1 SE $(n=2)$. See Table 2 for full species names

$1.3 \mathrm{~m}^{2} \mathrm{~g}^{-1} \mathrm{chl} \mathrm{a}$ at irradiance levels of 40,100 and $300 \mu \mathrm{mol}$ photons $\mathrm{m}^{-2} \mathrm{~s}^{-1}$, respectively. Two-way ANOVA on the effect of species and irradiance level confirmed the effect of irradiance on the $\hat{a}^{*}{ }_{\text {chla }}$ level in the stationary growth phase $(\mathrm{p}<0.0001)$ while irradiance had a smaller impact on $\hat{a}^{*}{ }_{\text {chl } a}$ in the exponential growth phase $(p=0.055)$. Increasing the availability of DIN lowered $\hat{a}^{*}{ }_{\text {chla }}$ from $16.5 \pm 2.1$ in N-depleted to $13.5 \pm 1.4 \mathrm{~m}^{2} \mathrm{~g}^{-1} \mathrm{chl} \mathrm{a}$ in N-replete cultures. Raising the availability of DIN from Redfield to a replete level, had no significant influence on $\hat{a}^{*}{ }_{\text {chla }}$ (Student-NewmanKeuls pairwise comparison, $\mathrm{p}<0.05)$.

\section{Modelling the variation in the spectrally averaged chl a-specific absorption}

Evaluating the effect of factors which directly affect the spectrally averaged $\hat{a}^{*}{ }_{\text {chla }}$ showed a negative relationship between $\hat{a}^{*}{ }_{\text {chla }}$ and the relative optical length of the phytoplankton, but a positive correlation with the carotenoid:chl a ratio (Table 3, Fig. 7). Further- more, $\hat{a}^{*}{ }_{\text {chla }}$ was weakly negatively correlated to the absorption efficiency $\left(Q_{\mathrm{a}}\right)$. An overall gradient in $\hat{a}^{*}{ }_{\text {chla }}$ from the smallest to the largest phytoplankton species was evident. The smaller phytoplankton cells, with high $\hat{a}^{*}$ chla coefficients, had a low relative optical length (i.e. low packaging) but high concentrations of carotenoids relative to chl $a$.

A similar approach was used to evaluate the effect of external factors on the variation in $\hat{a}^{*}{ }_{\text {chla }}$. A multiple linear regression model of $\hat{a}^{*}{ }_{\text {chla }}$ as a function of species, growth phase, irradiance and DIN level was used to de-

Table 3. Linear regression models of $\log \left(\hat{a}_{\text {chla }}^{*}\right)$ as a function of factors with effect on packaging. All variables were log-transformed in order to fullfill the requirements of the parametric analysis. ${ }^{*} \mathrm{p}<0.5,{ }^{* * * *} \mathrm{p}<0.0001$

\begin{tabular}{|lrccc|}
\hline Variables & Slope & Intercept & $\mathrm{r}^{2}$ & $\mathrm{p}$ \\
\hline Relative optical length & -0.47 & -1.26 & 0.57 & ${ }^{* * * *}$ \\
Carotenoid:chl $a$ & 1.01 & -1.72 & 0.18 & ${ }^{* * * *}$ \\
$Q_{\mathrm{a}}$ & -0.21 & -2.10 & 0.05 & ${ }^{*}$ \\
\hline
\end{tabular}




\section{Exponential growth phase Stationary growth phase}

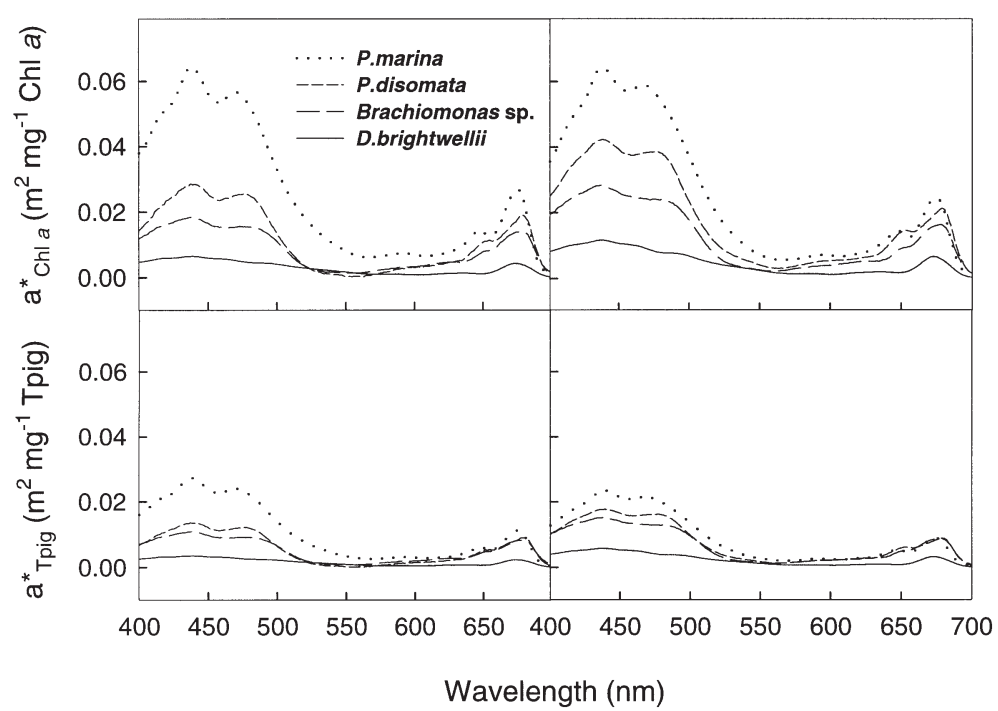

Fig. 5. Mean chl $a$ and total pigment-specific in vivo absorption spectra of the investigated phytoplankton species sampled in exponential and stationary growth $(\mathrm{n}=14)$. See Table 2 for full species names termine which parameter had the greatest impact on $\hat{a}^{*}{ }_{\text {chla }}$ (Table 4). In the model, species were assigned from 1 to 4 corresponding to increasing size, exponential and stationary growth phase were denoted as 1 and 2, the 3 irradiance levels were assigned their original values $(40,100$ and 300), and the numbers 16 and 85 were used as indicators of N-deplete (N:P ratio $=5), N$-Redfield $(\mathrm{N}: \mathrm{P}$ ratio $=16)$ and $\mathrm{N}$-replete $(\mathrm{N}: \mathrm{P}$ ration $=85)$ conditions. The model was run on the entire data set as well as on data from exponential and stationary growth considered separately (Table 4). Values of $\hat{a}^{*}$ chla were log-transformed in order to fulfil the requirements of a parametric model. The result of the first model, which included data from both growth phases, was highly significant and capable of explaining $85 \%$ of the variability in $\hat{a}^{*}{ }_{\text {chla. }}$ The models that only included data from either the exponential or stationary

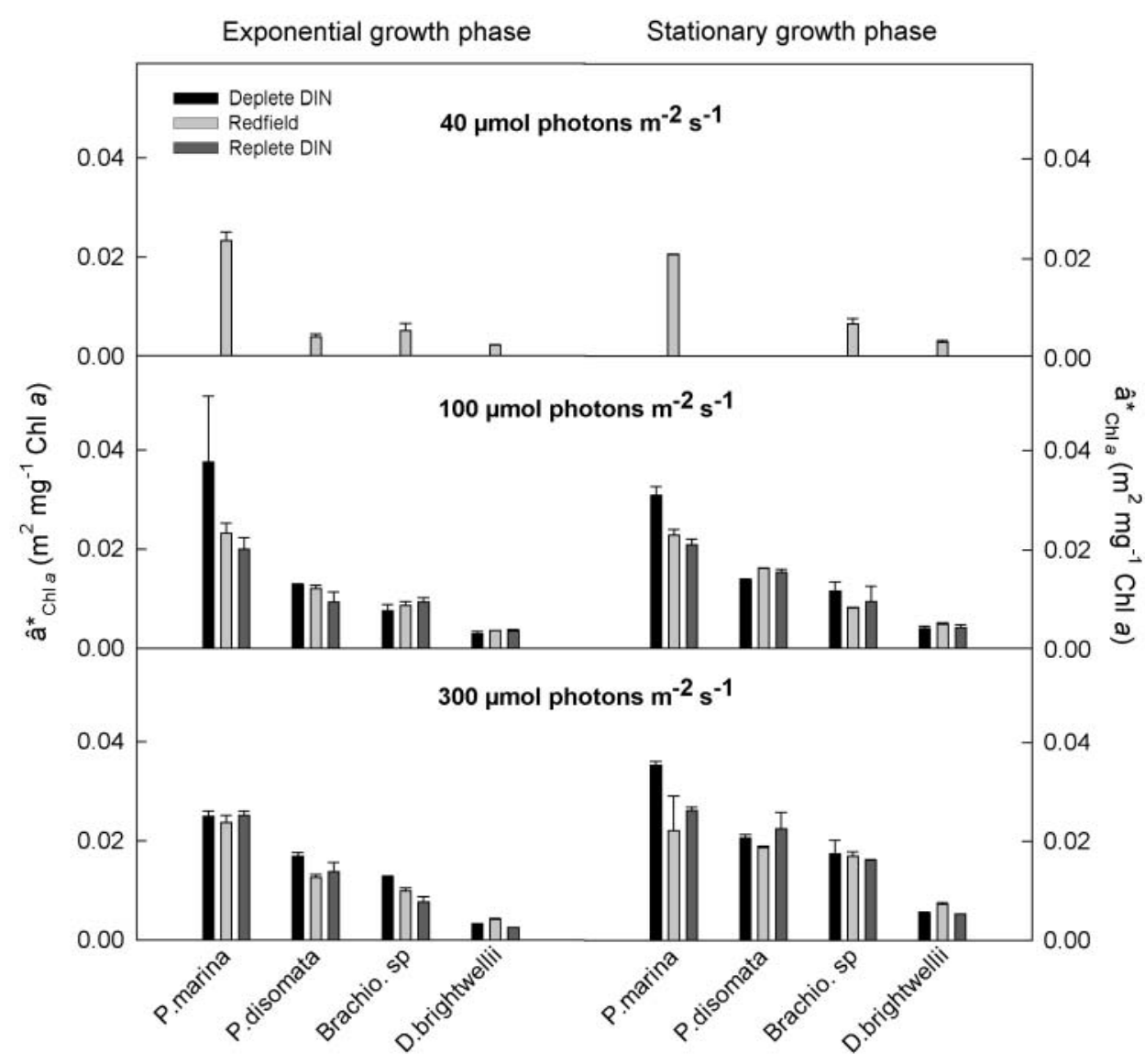

Fig. 6. Spectrally averaged $\mathrm{chl}$ a-specific absorption coefficient of phytoplankton species sampled in exponential and stationary growth. Phytoplankton species are presented in order of increasing cell size. All data are average \pm 1 SE $(n=2)$. See Table 2 for full species names 


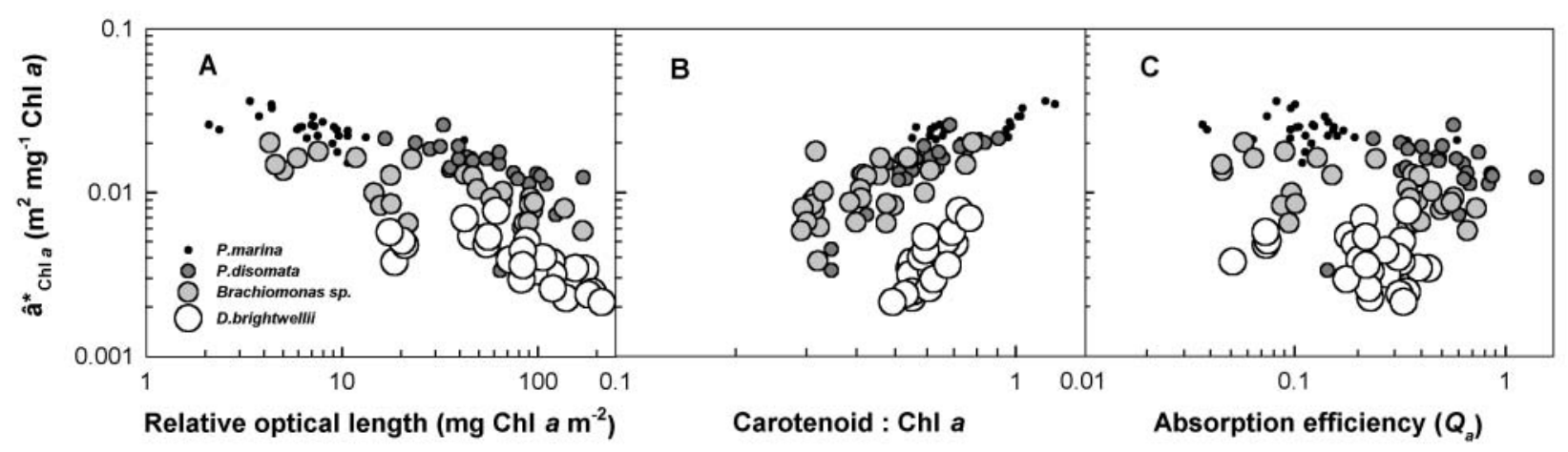

Fig. 7. Spectrally averaged chl a-specific absorption as a function of relative optical length (A), carotenoid:chl a ratio (B) and absorption effeciency (C) of the phytoplankton species. See Table 2 for full species names

Table 4. Multiple regression analysis of $\log \left(\hat{a}^{*}{ }_{\text {chla }}\right)$ as a function of species, growth phase, irradiance level and nutrient availability. ${ }^{* *} \mathrm{p}<0.01,{ }^{* * * *} \mathrm{p}<0.0001$. ns: not significant at the 0.05 level. The significance levels for all of the different models were $\mathrm{p}<0.0001$

\begin{tabular}{|c|c|c|c|c|c|}
\hline Model type & Variable & Overall & Coefficient & SS & $\mathrm{p}$ \\
\hline $\begin{array}{l}\text { Both growth } \\
\text { phases }\end{array}$ & $\begin{array}{l}\text { Constant } \\
\text { Species } \\
\text { Growth phase } \\
\text { Irradiance } \\
\text { Nutrients }\end{array}$ & $\mathrm{R}^{2}=0.85$ & $\begin{array}{l}-1.65 \\
-0.25 \\
0.14 \\
0.0007 \\
-0.0005\end{array}$ & $\begin{array}{l}8.60 \\
0.51 \\
0.60 \\
0.02\end{array}$ & $\begin{array}{c}{ }^{* * * *} \\
{ }^{* * * *} \\
* * * * \\
* * * * \\
\mathrm{nS}\end{array}$ \\
\hline $\begin{array}{l}\text { Exponential } \\
\text { growth phase }\end{array}$ & $\begin{array}{l}\text { Constant } \\
\text { Species } \\
\text { Irradiance } \\
\text { Nutrients }\end{array}$ & $\mathrm{R}^{2}=0.84$ & $\begin{array}{l}-1.43 \\
-0.28 \\
0.0006 \\
0.0006\end{array}$ & $\begin{array}{l}5.22 \\
0.23 \\
0.02\end{array}$ & $\begin{array}{c}* * * * \\
{ }^{* * * *} \\
{ }^{* *} \\
\mathrm{nS}\end{array}$ \\
\hline $\begin{array}{l}\text { Stationary } \\
\text { growth phase }\end{array}$ & $\begin{array}{l}\text { Constant } \\
\text { Species } \\
\text { Irradiance } \\
\text { Nutrients }\end{array}$ & $\mathrm{R}^{2}=0.87$ & $\begin{array}{l}-1.47 \\
-0.23 \\
0.0008 \\
0.0001\end{array}$ & $\begin{array}{l}3.43 \\
0.39 \\
0.01\end{array}$ & $\begin{array}{c}* * * * \\
* * * * \\
* * * * \\
\text { ns }\end{array}$ \\
\hline
\end{tabular}

growth phase gave very similar results (Table 4). According to the sum of squares, associated with the estimated coefficients in the models, the ability of the model which included both growth phases to explain the variability in $\hat{a}^{*}$ chla primarily depended on species and less on irradiance level and growth phase (Table 4). Species were similarly most important in the other model. $\mathrm{N}$ availability did not contribute significantly to explaining the variability in $\hat{a}^{*}{ }_{\text {chla }}$ in any of the models.

\section{DISCUSSION}

\section{Cellular acclimation to different growth conditions}

The carotenoid:chl a ratio, $\mathrm{C}: \mathrm{N}$ ratio and relative optical length differed significantly between the phytoplankton species studied. However, the same pattern in acclimation to irradiance, nutrient availability and growth phase was observed for all species. Low $\mathrm{N}$ availability caused a reduction in the cellular $\mathrm{N}$ and chl a content during stationary growth, especially evident in $\mathrm{N}$-deplete cultures and furthermore, enhanced the $\mathrm{C}: \mathrm{N}$ and carotenoid:chl a ratios. These findings suggest that chlorophyll synthesis was closely coupled to the internal $\mathrm{N}$ pool, which decreased significantly during stationary growth. This observation is consistent with the regulatory model of phytoplankton acclimation presented by Geider et al. (1998) stating that chl a synthesis is dependent on $\mathrm{N}$ assimilation and availability. The decline in cellular chl a content further decreased the relative optical length.

Yentsch \& Vaccaro (1958) and Heath et al. (1990) also found an inverse relationship between the carotenoid:chl a ratio and $\mathrm{N}$ content in algal cells. The common explanation for this relationship is that chlorophylls and some of the carotenoids decrease during $\mathrm{N}$ depletion while other carotenoids accumulate in the cells (Madriaga \& Joint 1992, Latasa \& Berdalet 1994, Latasa 1995, Schlüter et al. 1997). Accumulation of carotenoids has been explained as a photoprotective response (Demming-Adams 1990, Demers et al. 1991). 
Nutrient limitation can lead to large changes in the production of non-photosynthetic pigments (Sosik \& Mitchell 1991, Babin et al. 1996), a mechanism which is used commercially to enhance the production of carotenoids in microalgal mass cultures (Babin et al. 1996). In our experiments, reduced chl a content accounted for a decrease in the relative optical length of the algae as well as an increase in the carotenoid: chl a ratios in $\mathrm{N}$-depleted cultures, which did not experience a significant decrease in the cellular carotenoid content. These experimental data agree well with field observations, where significantly higher carotenoid: chl a ratios were found in oligotrophic oceanic waters than in eutrophic estuarine waters (Staehr et al. unpubl.). Low $\mathrm{N}$ availability, therefore, seems to have a less profound effect on the synthesis of N-free pigments such as carotenoids than on chl $a$, which contains $\mathrm{N}$.

Photoacclimation of phytoplankton cells has been shown to affect the intracellular pigment concentration and composition. In our study, all species acclimated to increasing irradiance by reducing their cellular chl a content within a few days. This result agrees well with Berner et al. (1989), who found significant changes in the intracellular pigment concentration of phytoplankton within $2 \mathrm{~d}$. Furthermore, a significant increase in the carotenoid:chl a ratio was observed with increasing irradiance. This observation agrees well with many previous studies (e.g. Mitchell \& Kiefer 1988, Berner et al. 1989, Sosik \& Mitchell 1991). The reduced cellular chl a content at high irradiance may account for the parallel increase in carotenoid:chl a ratio generally exhibited by the algae. However, an increased ratio may also reflect a combination of reduced chl a content and an increase in light protecting carotenoids. Of the measured pigments in our study (Table 2), zeaxanthin, $\beta$-carotene, diadinoxanthin and lutein can be assumed to be light-protecting pigments (Niyogi et al. 1997, Stuart et al. 1998) and the remaining pigments to be light capturing. Using this definition, we found a significant increase in the ratio of light-protecting: lightcapturing pigments with increasing irradiance $(0.07 \pm$ 0.01 over $0.11 \pm 0.01$ to $0.18 \pm 0.01)$. However, this increase was only caused by a reduction in lightcapturing pigments ( $48 \pm 21$ over $25 \pm 7$ to $19 \pm 5$ pg pigment cell $^{-1}$ ) since the content of light-protecting pigments remained consistently low $(2.9 \pm 1.2$ over $2.1 \pm 0.5$ to $2.0 \pm 0.6 \mathrm{pg}$ pigment cell ${ }^{-1}$ ). The changes in pigmentation observed here reduce the overall light absorption by the cells, thereby lowering the energy input at high light. This is probably a protection against photo-damage resulting from excitation of pigments. The low levels of production of photoprotecting pigments might be due to the absence of UV light in the experiments.

\section{Variations in chl a-specific in vivo absorption}

Variability in $a^{*}{ }_{\text {chla }}$ between species has been shown to originate from 3 sources: (1) differences in size and (2) intracellular chl a concentrations, both affecting the packaging of pigments; and (3) variations in pigment composition (e.g. Morel \& Bricaud 1981, Bricaud et al. 1983, Kirk 1994). The package effect is most important for species with either large cells and/or a high intracellular chl a concentration (Bricaud et al. 1988). Our results showed that the variation in $\hat{a}^{*}{ }_{\text {chla }}$ was mainly due to changes in pigment packaging, determined as the product of cell size and intracellular chl a content, and less to pigment composition (carotenoid:chl a ratio). As documented by several authors (e.g. Morel \& Bricaud 1981, Ciotti et al. 1997, 2002), the chl a-specific absorption spectra become flatter with increasing size of the phytoplankton. However, since pigment packaging and pigment composition covaried with phytoplankton cell size, the flattening effect must be attributed to a combination of the 2 processes.

Under natural conditions, light and nutrient regimes experienced by the phytoplankton can be important sources of variability in $a^{*}{ }_{\text {chla }}$ (Sosik \& Mitchell 1995). Several experiments have shown that $a^{*}{ }_{\text {chla }}$ can vary significantly as a function of growth irradiance (e.g. Sathyendranath et al. 1987, Mitchell \& Kiefer 1988, Berner et al. 1989, Moore et al. 1995) and availability of inorganic N (Herzig \& Falkowski 1989, Chalup \& Laws 1990, Sosik \& Mitchell 1991). In accordance with many previous studies (e.g. Falkowski \& LaRoche 1991), phytoplankton grown at high irradiances had low pigment packaging resulting in higher $a^{*}{ }_{\text {chla }}$. Furthermore, high nutrient availability has been found to increase the cellular chl a concentration after a few days, leading to a decrease in the $a^{*}{ }_{\text {chla }}$ (Sosik \& Mitchell 1991). Similarly, Sosik \& Mitchell (1995) found that $a^{*}{ }_{\text {chla }}$ of natural phytoplankton was significantly lower for samples collected at the nitracline than for samples collected above the nitracline. In accordance with these studies, we found that $\mathrm{N}$ starvation decreased the pigment packaging of the phytoplankton cells and increased the carotenoid:chl a ratio, a combination which logically resulted in higher $a^{*}{ }_{\text {chl }}$.

\section{CONCLUSIONS}

Growing 4 phytoplankton species under different irradiance and nutrient regimes introduced significant and expected changes in the cellular nutrient content, pigment packaging and composition, and $a^{*}$ chla. Despite the introduced variability, differences in the optical properties between the species were not diminished. The interspecies differences in optical proper- 
ties of the studied phytoplankton were primarily due to differences in cell size, which has a profound effect on pigment packaging and composition of the algae. The results suggest that photoacclimation (i.e. changes in pigment composition and packaging) to the prevailing growth conditions (light, temperature and nutrient availability) is less important than differences in phytoplankton composition (dominant cell size and pigment composition) for the variability recorded in $a^{*}{ }_{\text {chla }}$ in natural water samples.

Acknowledgements. This paper was prepared as a part of the DECO (Danish Environmental monitoring of COastal waters) project. The DECO project was financed by the Danish Earth Observation Program grant no. 9600667. Laboratory experiments were conducted as a part of the EU MAST III project MIDAS (contract no. MAS3-CT97-0154) and also supported by the Danish National Science Research Council. We are grateful to Winnie Martinsen and Susanne Hemmingsen for analytical and technical support.

\section{LITERATURE CITED}

Babin M, Morel A, Claustre H, Bricaud A, Kolber Z, Falkowski PG (1996) Nitrogen- and irradiance-dependent variations of the maximum quantum yield of carbon fixation in eutrophic, mesotrophic and oligotrophic marine systems. Deep-Sea Res I 43(8):1241-1272

Berner T, Wyman K, Falkowski PG (1989) Photoadaption and the package effect in Dunaliella tertiolecta (Chlorophyceae). J Phycol 25:70-78

Bricaud A, Stramski D (1990) Spectral absorption coefficients of living phytoplankton and nonalgal biogenous matter: a comparison between the Peru upwelling area and the Sargasso Sea. Limnol Oceanogr 35:562-582

Bricaud A, Morel A, Prieur L (1983) Optical efficiency factors of some phytoplankters. Limnol Oceanogr 28:816-832

Bricaud A, Bédhomme AL, Morel A (1988) Optical properties of diverse phytoplanktonic species: experimental results and theoretical interpretation. J Plankton Res 10(5): 851-873

Bricaud A, Babin M, Morel A, Claustre H (1995) Variability in the chlorophyll-specific absorption coefficients of natural phytoplankton: analysis and parameterization. J Geophys Res 100:13321-13332

Chalup MS, Laws EA (1990) A test of the assumptions and predictions of recent microalgal growth models with the marine phytoplankter Pavlova lutheri. Limnol Oceanogr 35:583-596

Ciotti AM, Cullen JJ, Roesler CR, Lewis MR (1997) The influence of phytoplankton size structure on the spectral attenuation coefficient in the upper ocean. SPIE 2963:380-385 (available at: http://spie.org/app/Publications)

Ciotti AM, Lewis MR, Cullen JJ (2002) Assessment of the relationship between dominant cell size in natural phytoplankton communities and the spectral shape of the absorption coefficient. Limnol Oceanogr 47:404-417

Cleveland JS (1995) Regional models for phytoplankton absorption as a function of chlorophyll a concentration. J Geophys Res 100:13333-13344

Demers S, Roy S, Gagnon R, Vignault C (1991) Rapid lightinduced changes in cell fluorescence and in xanthophyllcycle pigments of Alexandrium excavatum (Dinophyceae) and Thalassiosira pseudonana (Bacillariophyceae): a photoprotection mechanism. Mar Ecol Prog Ser 76:185-193

Demming-Adams B (1990) Carotenoids and photoprotection in plants: a role for the xanthophyll zeaxanthin. Biochem Biophys Acta 1020:1-20

Falkowski PG, LaRoche J (1991) Acclimation to spectral irradiance in algae. J Phycol 27:8-14

Falkowski PG, Dubinsky Z, Wyman K (1985) Growth-irradiance relationships in phytoplankton. Limnol Oceanogr 30: 311-321

Geider RJ, Platt T, Raven JA (1986) Size dependence of growth and photosynthesis in diatoms: a synthesis. Mar Ecol Prog Ser 30:93-104

Geider RJ, MacIntyre HL, Kana TM (1998) A dynamic regulatory model of phytoplankton acclimation to light, nutrients, and temperature. Limnol Oceanogr 43(4):679-694

Gordon HR, Morel A (1983) Remote assessment of ocean color for interpretation of satellite visible imagery: a review. In: Barber RT, Mooers NK, Bowman MJ, Zeitzschel B (eds) Lecture notes on coastal and estuarine studies. SpringerVerlag, New York, p 114

Heath MR, Richardson K, Kiørboe T (1990) Optical assessment of phytoplankton nutrient depletion. J Plankton Res 12:381-396

Herzig R, Falkowski PG (1989) Nitrogen limitation in Isochrysis galbana (Haptophyceae). I. Phytosynthetic energy conversion and growth efficiencies. J Phycol 25:462-471

Hoepffner N, Sathyendranath S (1992) Bio-optical characteristics of coastal waters: absorption spectra of phytoplankton and pigment distribution in the western North Atlantic. Limnol Oceanogr 37:1660-1679

Kirk JTO (1994) Light and photosynthesis in aquatic ecosystems, 2nd edn. Cambridge University Press, New York

Kishino M, Takahashi M, Okami N, Ichimura S (1985) Estimation of the spectral absorption coefficients of phytoplankton in the sea. Bull Mar Sci 37:634-642

Latasa M (1995) Pigment composition or Heterocapsa sp. and Thalassiosira weisslogii growing in batch cultures under different irradiances. Sci Mar 59:25-37

Latasa M, Berdalet E (1994) Effect of nitrogen or phosphorus starvation on pigment composition of cultured Heterocapsa sp. J Plankton Res 16:83-94

Lutz VA, Sathyendranath S, Head EJH (1996) Absorption coefficient of phytoplankton: regional variations in the North Atlantic. Limnol Oceanogr 135:197-213

Madriaga I, Joint I (1992) A comparative study of phytoplankton physiological indicators. J Exp Mar Biol Ecol 158: 149-165

Markager S, Vincent WF (2001) Light absorption by phytoplankton: development of a matching parameter for algal photosynthesis under different spectral regimes. J Plankton Res 23:1373-1384

Mitchell BG, Kiefer DA (1988) Chlorophyll a specific absorption and fluorescence excitation spectra for light-limited phytoplankton. Deep-Sea Res 35:639-663

Moore LR, Goericke R, Chisholm SW (1995) Comparative physiology of Synechococcus and Prochlorococcus: influence of light and temperature on growth, pigments, flourescence and absorptive properties. Mar Ecol Prog Ser 116:259-275

Morel A, André JM (1991) Pigment distribution and primary production in the western Mediterranean as derived and modeled from coastal zone color scanner observations. J Geophys Res 96:12685-12698

Morel A, Bricaud A (1981) Theoretical results concerning light absorption in a discrete medium, and applications to specific absorption of phytoplankton. Deep-Sea Res 28:1375-1393 
Niyogi KK, Björkman O, Grossman AR (1997) The roles of specific xanthophylls in photoprotection. Proc Natl Acad Sci USA 94:14162-14167

Platt T, Sathyendranath S (1988) Oceanic primary production: estimation by remote sensing at local and regional scales. Science 241:1613-1620

Platt T, Sathyendranath S, Longhurst A (1995) Remote sensing of primary production in the ocean: promise and fulfilment. Phil Trans R Soc Lond Ser B Biol Sci 348: 191-202

Sathyendranath S, Lazzara L, Prieur L (1987) Variations in the spectral values of specific absorption of phytoplankton. Limnol Oceanogr 32:403-415

Sathyendranath S, Longhurst A, Caverhill CM, Platt T (1995) Regionally and seasonally differentiated primary production in the North Atlantic. Deep-Sea Res Part I 43: 1773-1802

Schlüter L, Havskum H (1997) Phytoplankton pigments in relation to carbon content in phytoplankton communities. Mar Ecol Prog Ser 155:55-65

Editorial responsibility: Otto Kinne (Editor),

Oldendorf/Luhe, Germany
Schlüter L, Riemann B, Søndergaard M (1997) Nutrient limitation in relation to phytoplankton carotenoid/chlorophyll a ratios in freshwater mesocosms. J Plankton Res 19(7): 891-906

Sosik HM, Mitchell BG (1991) Absorption, fluorescence, and quantum yield for growth in nitrogen-limited Dunaliella tertiolecta. Limnol Oceanogr 36:910-921

Sosik HM, Mitchell BG (1995) Light absorption by phytoplankton, photosynthetic pigments and detritus in the California current system. Deep-Sea Res Part I 42: $1717-1748$

Stuart V, Sathyendranath S, Platt T, Maass H, Irwin BD (1998) Pigments and species composition of natural phytoplankton populations: effect on the absorption spectra. J Plankton Res 20:187-217

Yentsch CS, Phinney DA (1989) A bridge between ocean optics and microbial ecology. Limnol Oceanogr 34(8): 1694-1705

Yentsch CS, Vaccaro RF (1958) Phytoplankton nitrogen in the oceans. Limnol Oceanogr 3:443-448

Submitted: October 11, 2001; Accepted: March 26, 2002

Proofs received from author(s): July 3, 2002 